\title{
Effects of Cultivars and Fungicides on Rice Sheath Blight, Yield, and Quality
}

\author{
D. E. Groth, Professor, and J. A. Bond, Former Assistant Professor, Rice Research Station, Louisiana Agricultural \\ Experiment Station, Louisiana State University Agricultural Center, Rayne 70578
}

\begin{abstract}
Groth, D. E., and Bond, J. A. 2007. Effects of cultivars and fungicides on rice sheath blight, yield, and quality. Plant Dis. 91:1647-1650.

The development of sheath blight (Rhizoctonia solani)-resistant rice (Oryza sativa) cultivars will allow producers to use less fungicide and to avoid significant reductions in grain and milling yields. Among cultivars currently in cultivation in the southern United States rice-producing region, sheath blight resistance levels range from very susceptible to moderately susceptible. A study was conducted to determine the response of cultivars with different levels of susceptibility to sheath blight inoculations and fungicide applications and to determine the impact of sheath blight disease development on rice yield and quality. Sheath blight epidemics in field plots were initiated by inoculation at the panicle differentiation growth stage from 2003 through 2005. Azoxystrobin at $0.17 \mathrm{~kg}$ a.i. $\mathrm{ha}^{-1}$ and flutolanil at $0.56 \mathrm{~kg}$ a.i. ha ${ }^{-1}$ were applied in sequential applications at midboot and 50 to $70 \%$ heading. Inoculation significantly increased sheath blight severity and incidence and caused yield losses of $4 \%$ in moderately susceptible cv. Francis to $21 \%$ in very susceptible cv. Cocodrie. Milling yield was affected to a lesser extent. Fungicide treatments reduced sheath blight incidence and severity regardless of cultivar. Azoxystrobin was more effective than flutolanil in minimizing yield loss due to sheath blight in all cultivars except Francis.
\end{abstract}

Additional keywords: grain quality

Sheath blight, caused by Rhizoctonia solani J.G. Kühn AG1-1A (teleomorph: Thanatephorus cucumeris (A.B. Frank) Donk.) $(4,24)$, is the most important rice (Oryza sativa L.) disease in the southern United States $(8,16,25)$. Under conditions favorable for disease development, rice grain yield losses, ranging from 4 to $50 \%$, have been attributed to sheath blight $(11,16,21,22)$. Disease severity is dependent on inoculum amount, crop growth stage at infection, environmental conditions, varietal resistance, and cultural management $(4,10,25,26)$. High sheath blight intensity in the United States Gulf Coast region is attributed to cultural practices of modern rice production, including use of semidwarf cultivars, intensive nitrogen fertilization, high plant populations common in direct-seeded rice culture, and rotation with soybean, an alternative host for the pathogen $(8,11)$. Losses due to sheath blight result from reductions in

Corresponding author: D. E. Groth

E-mail: dgroth@agcenter.lsu.edu

Current address of J. A. Bond: Assistant research professor, Delta Research and Extension Center, Mississippi State University, Stoneville 38776.

Approved for publication by the Director of the Louisiana Agricultural Experiment Station as manuscript number 07-61-0136.

Accepted for publication 18 July 2007.

doi:10.1094/PDIS-91-12-1647

(c) 2007 The American Phytopathological Society grain yield and grain quality and increased lodging in the first (main) crop. Reductions in plant population in the second (ratoon) crop cause additional yield reductions $(10,21)$

A major goal of all rice-breeding programs in the southern United States is to improve disease resistance, especially to sheath blight. Development of rice cultivars with adequate levels of disease resistance potentially could reduce or eliminate losses due to disease without the use of fungicides. Other benefits of diseaseresistant cultivars include reduced disease development and subsequent inoculum production and increased grain and milling yields, a key component in grain quality and price (5).

Azoxystrobin and flutolanil are labeled on rice in the United States for sheath blight control (5). These fungicides are more effective than propiconazole and other fungicides, including benomyl and iprodione, that are no longer labeled for sheath blight control in the United States. However, azoxystrobin and flutolanil are expensive and can be ineffective if applied at the wrong time or not economical if applied under conditions of low disease pressure $(6,7,9,14,15)$.

Historically, fungicide studies were conducted on very susceptible or susceptible cultivars. Therefore, information is limited on the effects of fungicide applications on sheath blight incidence and severity and rice yield of cultivars with varying levels of disease susceptibility. Preliminary studies suggested that yield losses and the benefits realized from a fungicide application are lower with less susceptible cultivars $(12,13)$. A fungicide application for sheath blight control is not justified until initial infections reach certain levels (treatment thresholds), which increase as cultivar susceptibility decreases $(1,12)$ The objectives of this study were to determine the impact of sheath blight on rice grain and milling yields of very susceptible to moderately susceptible cultivars and to characterize the effects of fungicide applications on cultivars with varying susceptibility levels to maximize sheath blight control and grain and milling yields.

\section{MATERIALS AND METHODS}

Experiments were conducted at the Louisiana State University Agricultural Center's Rice Research Station in Crowley, LA. Long-grain cultivars included the very susceptible cvs. Cocodrie (PI 606331) (17) and Cypress (PI 561734) (18), the susceptible cv. Cheniere (PI 634719) (20), and the moderately susceptible cv. Francis (PI 632447) (23). A moderately susceptible medium-grain cultivar, Bengal (PI 561735) (19), also was included. All cultivars were drill-seeded on 3 April 2003 and 23 and 29 March 2004 and 2005, respectively, at the rate of $136 \mathrm{~kg} \mathrm{ha}^{-1}$. Plots were 1.2 by 4.9 $\mathrm{m}$ and consisted of seven rows spaced 18 $\mathrm{cm}$ apart. Soil type was a Crowley silt loam (pH 6.0, clay $12 \%$, silt $71 \%$, sand $17 \%$, cation exchange capacity [CEC] 9.4 $\left.\mathrm{kg}^{-1}\right)$. Fertilizer (N-P-K) was incorporated 1 day before planting at the rate of 24-67$67 \mathrm{~kg} \mathrm{ha}^{-1}$. Agronomic, weed, and insect management practices followed current standard recommendations (1). Nitrogen was applied prior to flooding rice in the three- to four-leaf stage at $133 \mathrm{~kg} \mathrm{ha}^{-1}$ as urea and after flooding at $51 \mathrm{~kg} \mathrm{ha}^{-1}$ as urea at the beginning of stem internode elongation.

Inoculation. Plots were inoculated at the panicle differentiation (panicle $0.2 \mathrm{~cm}$ in length) (1) growth stage with a virulent isolate of $R$. solani (LR172) collected from a naturally infected rice plant (cv. Lebonnet) in Louisiana in 1972 by Dr. M. C. Rush. Inoculum was produced on a moist, autoclaved rice grain/rice hull mixture $(1: 2, \mathrm{vol} / \mathrm{vol})$ incubated for 12 to 14 days at $30^{\circ} \mathrm{C}$. The grain-hull inoculum was broken into small (3- to 7-mm-diameter) particles consisting of several rice grains held together by fungal mycelia. Approximately $100 \mathrm{~cm}^{3}\left(17 \mathrm{~cm}^{3} \mathrm{~m}^{-2}\right)$ was distributed evenly over each plot by hand, except for noninoculated controls. Inoculation 
dates were 25, 10, and 8 June 2003, 2004, and 2005, respectively.

Fungicide treatments. Azoxystrobin (Quadris 2.08 SC; Syngenta, Raleigh, NC) and flutolanil (Moncut 70 DF; Gowan, Yuma, AZ) were applied at the most commonly recommended rates of 0.17 and $0.56 \mathrm{~kg}$ a.i. $\mathrm{ha}^{-1}$, respectively, in sequential applications at the boot (5- to $10-\mathrm{cm}$ panicle in the boot) and heading (50 to $70 \%$ of panicles emerging from the boot) growth stages (1). Treatments were applied at a delivery rate of 140 liters ha ${ }^{-1}$ with a $\mathrm{CO}_{2^{-}}$ pressurized backpack sprayer. Boot applications were made on 18,11 , and 20 June in 2003, 2004, and 2005, respectively; and heading applications were made on 30 and 28 June in 2003 and 2004, respectively, and 15 July 2005. Nonsprayed inoculated and noninoculated checks were included.

Disease assessments and yield determination. Plots were evaluated for sheath blight development approximately 1 week before maturity and assigned severity ratings using a semilinear scale $(6,10,28)$ on 29, 20, and 27 July 2003, 2004, and 2005, respectively. At the same times, disease incidence was determined by examining 100 stems per plot (25 stems at four locations in the center four rows of each plot) and calculating percentage of symptomatic stems.

On 8 August, 28 July, and, 11 August in 2003, 2004, and 2005, respectively, the center four rows of each plot were harvested with a small-plot combine. Grain yield and moisture were determined and rice yields were adjusted to $120 \mathrm{~g} \mathrm{~kg}^{-1}$ moisture content. A 125-g grain subsample was collected from each harvest sample for determining milling percentages of whole (unbroken grains) and total rice (broken and whole grains). The subsample was hulled with a McGill Sheller (RAPSCO, Brookshire, TX), setting 19 for long-grain cultivars and setting 23 for the mediumgrain cultivar, to remove the lemma and palea. The resulting brown rice then was processed in a McGill Miller (RAPSCO) for $30 \mathrm{~s}$ to remove the bran layers and part of the embryo. The milled sample was weighed to determine total milled yield percentages, then placed on a Grainman grain separator (Grain Machinery Manufacturing Corporation, Miami) with no. 10 and 11 plates for long-grain cultivars and no. 135 and 10 plates for the medium-grain cultivar to remove broken kernels. Whole kernels were weighed to determine whole rice grain yield. Milling yield percentages were calculated as [(weight/125) $\times 100]$. Whole rice grain milling yield was considered commercially acceptable if it met the standard industry values for rice of $55 \%$ whole rice grain and $70 \%$ total rice.

Data analysis. Treatments were replicated four times in a randomized complete block design with a factorial arrangement of five rice cultivars and four sheath blight inoculation and fungicide treatment combinations. Sheath blight inoculation and fungicide treatment combinations included the following: noninoculated and nonsprayed, inoculated and nonsprayed, inoculated and azoxystrobin-treated, and inoculated and flutolanil-treated.

Data were analyzed using the Mixed Procedure (SAS Institute, Cary, NC). Year was used as a random effect parameter testing all possible interactions of cultivar and sheath blight inoculation-fungicide treatment combinations. Years, replications (nested within years), and all possible interactions containing these effects were considered random effects. Cultivar and sheath blight inoculation-fungicide treatment combinations were considered fixed effects. Considering year as an environmental or random effect permits inferences about treatments to be made over a range of environments (3). A similar statistical approach has been used successfully by other researchers and in other studies $(2,7,29)$. Type III statistics were used to test all possible fixed effects or interactions between the fixed effects, and a least significant difference test at $P \leq 0.05$ was used to determine significant differences among least square means.

\section{RESULTS}

In plots inoculated with $R$. solani, initial symptoms developed on 10 to $20 \%$ of the stems within 7 to 10 days of inoculation, and these infection levels were within sheath blight treatment thresholds for the cultivars in the study $(1,11)$. Light infestations of sheath blight developed in the noninoculated plots but did not reach treatment threshold during the growing season. At the final rating date, noninoculated plots exhibited 20 to $44 \%$ infected stems with 3.1 to 5.4 severity ratings. Severe sheath blight developed uniformly each year in the inoculated/nonsprayed treatments, averaging 50 to $90 \%$ stems infected and 5.6 to 8.0 severity ratings. No other major yield-reducing diseases were detected at significant levels in any year, although some minor diseases developed.

The main effects of cultivar and sheath blight inoculation-fungicide treatment combination were significant for sheath blight incidence and severity and whole rice grain yield (Table 1). An interaction between cultivar and sheath blight inoculation-fungicide treatment combination was detected for rice grain yield. The main effects and interaction of cultivar and sheath blight inoculation-fungicide treatment combination were not significant for total milling yield. However, total milling yield was slightly below commercially acceptable levels (at least 70\%) and ranged from 66 to $69 \%$ across all treatments (data not presented).

Pooled across sheath blight inoculationfungicide treatment combinations, the very susceptible Cocodrie and Cypress and the susceptible Cheniere exhibited similar values for disease incidence, which were greater than the disease incidence for the moderately susceptible cvs. Francis and Bengal (Table 2). Although Cheniere had a disease incidence similar to those of Cocodrie and Cypress, sheath blight severity

Table 2. Effect of cultivar on sheath blight incidence and severity and whole rice grain yield at Crowley, LA, from 2003 to $2005^{\mathrm{w}}$

\begin{tabular}{lcccc}
\hline Cultivar & $\begin{array}{c}\text { Sheath blight } \\
\text { susceptibility }^{\mathbf{x}}\end{array}$ & $\begin{array}{c}\text { Incidence }^{\mathbf{y}} \\
(\boldsymbol{\%})\end{array}$ & $\begin{array}{c}\text { Severity } \\
(\mathbf{0} \text { to } \mathbf{)})^{\mathbf{z}}\end{array}$ & $\begin{array}{c}\text { Whole rice grain } \\
\text { yield }(\boldsymbol{\%})\end{array}$ \\
\hline Cocodrie & VS & $51 \mathrm{a}$ & $5.5 \mathrm{a}$ & $59.5 \mathrm{a}$ \\
Cypress & VS & $47 \mathrm{a}$ & $5.2 \mathrm{a}$ & $61.6 \mathrm{a}$ \\
Cheniere & S & $43 \mathrm{a}$ & $4.5 \mathrm{~b}$ & $59.3 \mathrm{a}$ \\
Francis & MS & $30 \mathrm{~b}$ & $4.1 \mathrm{c}$ & $55.9 \mathrm{~b}$ \\
Bengal & MS & $33 \mathrm{~b}$ & $3.8 \mathrm{c}$ & $60.7 \mathrm{a}$ \\
\hline
\end{tabular}

${ }^{\mathrm{w}}$ Data pooled over years and sheath blight inoculation-fungicide treatment combinations. Means followed by same letter for each parameter are not significantly different at $P=0.05$.

${ }^{x}$ Sheath blight susceptibility levels included very susceptible (VS), susceptible (S), and moderately susceptible (MS).

y Percentage of stems infected with sheath blight at approximately 1 week before harvest.

${ }^{z}$ Sheath blight rated 1 week before harvest on a 0 -to- 9 scale where $0=$ no disease and $9=$ plants dead and collapsed.

Table 1. Significance ( $P$ value) of the main effects of cultivar and sheath blight inoculation-fungicide treatment combination (treatment) and interactions among the main effects pooled across years

\begin{tabular}{lccccc}
\hline & \multicolumn{4}{c}{$\boldsymbol{P}$ value } \\
\cline { 2 - 6 } Effect (df) & Incidence & Severity & Grain yield & Whole rice grain yield & Total milling yield \\
\hline Cultivar (4) & 0.0016 & $<0.0001$ & 0.0117 & 0.0045 & 0.0830 \\
Treatment (3) & 0.0217 & 0.0004 & 0.0002 & $<0.0001$ & 0.3065 \\
Cultivar $\times$ treatment (12) & 0.0996 & 0.1690 & 0.0067 & 0.7237 & 0.9254 \\
\hline
\end{tabular}


was less for Cheniere compared with the severities on these cultivars (Table 2).

Sheath blight susceptibility did not appear to influence whole rice grain yield. Cocodrie, Cypress, Cheniere, and Bengal produced similar whole rice grain yields, which were greater than that for Francis (Table 2). Whole rice grain milling yield was commercially acceptable (at least $55 \%$ ) for all cultivars pooled across sheath blight inoculation-fungicide treatment combinations.

Sheath blight incidence and severity ratings were greater for inoculated/nonsprayed treatments compared with noninoculated/nonsprayed treatments pooled across cultivar (Table 3). Pooled across cultivar, flutolanil and azoxystrobin reduced sheath blight incidence and severity to the level of the noninoculated/ nonsprayed treatment. Sheath blight incidence was reduced, with at least $42 \%$ fewer infected stems following fungicide application. Sheath blight severity was reduced 2.8 and 3.2 points following flutolanil and azoxystrobin, respectively, compared with the inoculated/nonsprayed treatment. Whole rice grain yields in fungicide-treated plots were equivalent to whole rice grain yields in the noninoculated/nonsprayed plots and greater than in the inoculated/nonsprayed plots.

For rice grain yield, the cultivars responded differently to the inoculationfungicide treatment combinations (Table 4). Although treatment with azoxystrobin produced the highest yield for each cultivar, the yield response for Cypress was less than for the other cultivars. Compared with the inoculated/nonsprayed check, treatment with flutolanil increased yield for all cultivars except Bengal. These differences appear to be responsible for the significant cultivar-inoculation and treatment interaction (Table 1) for this variable.

\section{DISCUSSION}

Incidence and severity of sheath blight from natural inoculum were low in all years. The infestations that did develop in the noninoculated/nonsprayed plots were from inoculum movement from inoculated plots that occurred late in the season or some natural inoculum in the field and were confined to the lower third of the plant, causing light damage. With inoculation, sheath blight developed and caused significant grain yield reductions for very susceptible and susceptible rice cultivars but not for the moderately susceptible cultivars. The difference between the lightly diseased, noninoculated/nonsprayed and the inoculated/nonsprayed controls indicated that sheath blight can cause a 14 to $17 \%$ grain yield loss in very susceptible and susceptible cultivars and a 4 to $6 \%$ grain yield loss in moderately susceptible cultivars with an additional 2 percentage points reduction $(3 \%)$ loss in whole rice grain yield across all cultivars (Tables 3 and 4). The noninoculated/unsprayed treatments represent light to moderate disease conditions often found in commercial fields where fungicides usually are not recommended (12).

Table 3. Effect of sheath blight inoculation-fungicide treatment combinations on sheath blight incidence, severity, and whole grain yield at Crowley, LA, from 2003 to $2005^{\mathrm{w}}$

\begin{tabular}{llccc}
\hline Inoculation & $\begin{array}{c}\text { Fungicide } \\
\text { treatment }^{\mathbf{x}}\end{array}$ & $\begin{array}{c}\text { Incidence } \\
(\boldsymbol{\%})^{\mathbf{y}}\end{array}$ & Severity $^{\mathbf{z}}$ & $\begin{array}{c}\text { Whole rice grain } \\
\text { yield (\%) }\end{array}$ \\
\hline Noninoculated & Nonsprayed & $34 \mathrm{~b}$ & $4.3 \mathrm{~b}$ & $59.7 \mathrm{a}$ \\
Inoculated & Nonsprayed & $73 \mathrm{a}$ & $6.7 \mathrm{a}$ & $58.1 \mathrm{~b}$ \\
Inoculated & Flutolanil & $31 \mathrm{~b}$ & $3.9 \mathrm{~b}$ & $59.6 \mathrm{a}$ \\
Inoculated & Azoxystrobin & $26 \mathrm{~b}$ & $3.5 \mathrm{~b}$ & $60.3 \mathrm{a}$ \\
\hline
\end{tabular}

${ }^{\mathrm{w}}$ Data pooled over years and cultivar. Means followed by same letter for each parameter are not significantly different at $P=0.05$.

${ }^{x}$ Azoxystrobin (Quadris $2.08 \mathrm{SC}$, Syngenta, Raleigh, NC) at $0.17 \mathrm{~kg}$ a.i. ha ${ }^{-1}$ and flutolanil (Moncut $70 \mathrm{DF}$, Gowan, Yuma, AZ) at $0.56 \mathrm{~kg}$ a.i. ha ${ }^{-1}$ applied in sequential applications to rice in the boot (5to $10-\mathrm{cm}$ panicle in the boot) and heading (50 to $70 \%$ of panicles emerging from the boot) growth stages.

${ }^{y}$ Percentage of stems infected with sheath blight at approximately 1 week before harvest.

${ }^{\mathrm{z}}$ Sheath blight rated 1 week before harvest on a 0 -to- 9 scale where $0=$ no disease and $9=$ plants dead and collapsed.
When fungicides were used, grain yield increased as much as $31 \%$ compared with the inoculated/nonsprayed treatments. Some losses (in the noninoculated/ nonsprayed treatment) were due to inoculum movement from inoculated plots or natural sheath blight, and some increases (in fungicide-treated plots) were attributed to control of minor diseases. Yield losses observed in the inoculated/nonsprayed treatments are typical for heavily infested commercial rice fields and very important to the economic return a rice producer would receive for his crop. Under current economic conditions, this loss is $\$ 272 \mathrm{ha}^{-1}$ comparing the azoxystrobin treatment to the inoculated nonsprayed treatment for Cocodrie.

These disease levels and yield reductions are comparable with previous studies conducted in small plots and commercial fields on modern cultivars $(6,7,10,14)$. Studies on older, very susceptible cultivars demonstrated yield losses from 40 to $50 \%$, with reductions of up to 13 percentage points $(23 \%)$ in whole rice grain yields $(16,21,22)$. Apparently, current cultivars, if not less susceptible, are more tolerant than older cultivars, possibly due to their ability to resist lodging when heavily diseased, which is associated with the fungus' inability to penetrate the culm (D. E. Groth, personal observations).

Sheath blight was controlled effectively with azoxystrobin and flutolanil applied at boot and heading growth stages on the very susceptible and susceptible cultivars. Fungicide treatments on moderately susceptible cultivars appeared to be less effective in increasing yields than fungicide treatments applied to susceptible and very susceptible cultivars. Fungicide applications are recommended only if disease develops to a level that can cause significant loss because azoxystrobin and flutolanil cost approximately $\$ 118$ and $\$ 102$ $\mathrm{ha}^{-1}$, respectively. In addition, sheath blight does not develop to treatable levels every year (10). Fungicide treatment is based on scouting rice fields and applying fungicides only when treatment thresholds are exceeded $(1,12)$.

Fungicide applications commonly have been used in the southern United States rice production $(6,10)$. Historically, two fungicide applications often were required

Table 4. Effect of cultivar and sheath blight inoculation-fungicide treatment combination on rice grain yield at Crowley, LA, from 2003 to 2005

\begin{tabular}{|c|c|c|c|c|c|}
\hline \multirow[b]{2}{*}{ Cultivar } & \multirow[b]{2}{*}{ Susceptibility $^{\mathrm{y}}$} & \multicolumn{4}{|c|}{ Yield $\left(\mathrm{kg} \mathrm{ha}^{-1}\right)^{\mathrm{x}}$} \\
\hline & & Noninoculated/nonsprayed & Inoculated/nonsprayed & Inoculated/azoxystrobin-treated $^{\mathbf{z}}$ & Inoculated/flutolanil-treated $^{\mathrm{z}}$ \\
\hline Cocodrie & VS & $9,266 \mathrm{~d}-\mathrm{g}$ & $7,685 \mathrm{i}$ & $10,055 \mathrm{abc}$ & $9,245 \mathrm{~d}-\mathrm{g}$ \\
\hline Cypress & VS & $8,788 \mathrm{gh}$ & $7,710 \mathrm{i}$ & 9,402 def & $8,795 \mathrm{gh}$ \\
\hline Cheniere & $\mathrm{S}$ & 9,522 cde & $8,252 \mathrm{hi}$ & $10,326 \mathrm{a}$ & $9,692 \mathrm{bcd}$ \\
\hline Francis & MS & $9,395 \mathrm{~d}-\mathrm{g}$ & $8,875 \mathrm{fg}$ & $10,132 \mathrm{ab}$ & $9,687 \mathrm{bcd}$ \\
\hline Bengal & MS & $9,338 \mathrm{~d}-\mathrm{g}$ & 8,992 efg & $10,223 a b$ & $9,298 \mathrm{~d}-\mathrm{g}$ \\
\hline
\end{tabular}

\footnotetext{
${ }^{x}$ Means followed by same letter are not significantly different at $P=0.05$.
}

${ }^{y}$ Sheath blight susceptibility levels included very susceptible (VS), susceptible (S), and moderately susceptible (MS).

${ }^{\mathrm{z}}$ Azoxystrobin (Quadris 2.08 SC, Syngenta, Raleigh, NC) at $0.17 \mathrm{~kg}$ a.i. ha ${ }^{-1}$ and flutolanil (Moncut $70 \mathrm{DF}$, Gowan, Yuma, AZ) at $0.56 \mathrm{~kg}$ a.i. ha ${ }^{-1}$ applied in sequential applications to rice in the boot (5- to 10- $\mathrm{cm}$ panicle in the boot) and heading (50 to $70 \%$ of heads emerging from the boot) growth stages. 
to effectively control sheath blight (23); however, with the labeling of more potent fungicides and economic constraints that limit the number of applications, a single fungicide application is now the most common scenario. On very susceptible cultivars, single applications have been shown to be effective $(6,7)$. Future research should investigate the efficacy of single applications of fungicides across cultivars to determine whether a single application produces a response similar to that of the two applications utilized in this study.

The results of this research are based on cultivars grown in small plots. Caution is recommended when extrapolating small plot data to field situations because yield potential is higher in small plots. However, trends demonstrated in small-plot research typically translate to those observed in field situations $(8,9,13,14)$. This is especially true when multiple tests are conducted over several years. Yield increases due to fungicide applications and levels of disease development were similar between the experimental plots (inoculated plots) and farm locations (natural infestations in commercial fields) (6,9). Furthermore, many commercial fields and fungicide trials conducted within commercial fields have produced results similar to those of small-plot tests (13).

This study demonstrated that rice producers can reduce sheath blight by planting moderately susceptible cultivars and improve rice grain yield by applying azoxystrobin or flutolanil at midboot and 50 to $70 \%$ heading to susceptible and very susceptible cultivars. Azoxystrobin was more effective than flutolanil in minimizing yield loss due to sheath blight on all cultivars except the moderately susceptible Francis. However, fungicide applications are not warranted on moderately susceptible cultivars, especially if severe disease fails to develop on them.

\section{ACKNOWLEDGMENTS}

We thank R. Dunand and X. Sha for reviewing this manuscript and giving many helpful sugges- tions, the Louisiana Rice Research Board for providing support for this research and publication, and M. Frey and J. Nugent for their hard work and assistance in conducting this study.

\section{LITERATURE CITED}

1. Anonymous. 1999. Louisiana Rice Production Handbook. Louisiana State University Agricultural Center, Pub. No. 2321, Revised.

2. Bond, J. A., Walker, T. W., Bollich, P. K., Koger, C. H., and Gerard, P. 2005. Seeding rates for stale seedbed rice production in the mid-southern United States. Agron J. 97:15601563.

3. Carmer, S. G., Nyquist, W. E., and Walker, W. M. 1989. Least significant differences in combined analyses of experiments with two- or three-factor treatment designs. Agron. J. 81:665-672.

4. Gangopadhyay, S., and Chakrabarti, N. K. 1982. Sheath blight of rice. Rev. Plant Pathol. 61:451-460.

5. Groth, D. E. 1996. Two new fungicides to control rice diseases. La. Agric. 39:31-33.

6. Groth, D. E. 2005. Azoxystrobin rate and timing effects on rice sheath blight incidence and severity and rice grain and milling yields. Plant Dis. 89:1171-1174.

7. Groth, D. E., and J. A. Bond. 2006. Initiation of rice sheath blight epidemics and effects of application timing of azoxystrobin on disease incidence, severity, yield and milling yields. Plant Dis. 90:1073-1078.

8. Groth, D., and Lee, F. 2003. Rice diseases. Pages 413-436 in: Rice Origin, History, Technology, and Production. C. W. Smith and R. H. Dilday, eds. John Wiley \& Son, Hoboken, NJ.

9. Groth, D. E., and Rush, M. C. 1988. New fungicides to control sheath blight of rice. La. Agric. 31:8-9.

10. Groth, D. E., Rush, M. C., Giesler, G. G., and Hollier, C. A. 1993. Foliar fungicides for use in the management of rice diseases. La. Agric. Exp. Stn. Bull. No. 840 .

11. Groth, D. E., Rush, M. C., and Hollier, C. A. 1991. Rice diseases and disorders in Louisiana. La. Agric. Exp. Stn. Bull. No. 828.

12. Groth, D. E., Rush M. C., and Hollier, C. A. 1992. Prediction of rice sheath blight severity and yield loss based on early season infection. La. Agric. 35:20-23.

13. Groth, D. E., Rush, M. C., and Lindberg, G. D. 1990. Foliar fungicides for control of rice diseases in the United States. Pages 31-52 in: Pest Management in Rice. B. T. Grayson, M. B. Green, and L. G. Copping, eds. Elsevier, London.

14. Hollier, C. A., Groth, D. E., Levy, R. J., Courville, B. A., and McCorry, J. C. 1994. Rice yield differences: A comparison of fungicide application methods. Proc. Rice Tech. Wrkg. Grp. 25:88-89.

15. Jones, R. K., Belmar, S. B., and Jeger, M. J. 1987. Evaluation of benomyl and propiconazole for controlling sheath blight of rice caused by Rhizoctonia solani. Plant Dis. 71:222-225.

16. Lee, F. N., and Rush, M. C. 1983. Rice sheath blight: a major rice disease. Plant Dis. 67:829832 .

17. Linscombe, S. D., Bollich, P. K., Groth, D. E., White, L. M., and Dunand R. T. 2000. Registration of 'Cocodrie' rice. Crop Sci. 40:294.

18. Linscombe, S. D., Jodari, F., McKenzie, K. S. Bollich, P. K., Groth, D. E., and White, L. M. 1993. Registration of Cypress rice. Crop Sci. 33:355

19. Linscombe, S. D., Jodari, F., McKenzie, K. S., Bollich, P. K., Groth, D. E., and White, L. M. 1993. Registration of Bengal rice. Crop Sci. 33:645-646.

20. Linscombe, S. D., Sha, X., Beard, K., Chu, Q. R., Groth, D. E., White, L. M. Dunand, R. T., and Bollich P. K. 2006. Registration of Cheniere rice. Crop Sci. 46:1814-1815.

21. Marchetti, M. A. 1983. Potential impact of sheath blight on yield and milling quality of short statured rice lines in the southern United States. Plant Dis. 67:162-165.

22. Marchetti, M. A., and Bollich, C. N. 1991 Quantification of the relationship between sheath blight severity and yield loss in rice. Plant Dis. 75:773-775.

23. Moldenhauer, K. A. K., Gibbons, J. W., Lee, F. N., Bernhardt, J. L., Wilson, C. E., Cartwright, R. D., Anders, M. M., Norman, R. J., Slaton, N. A., Blocker, M. M., Tolbert, A. C., Taylor, K., and Bulloch, J. M. 2007. Registration of Francis rice. Crop Sci. 47:443-444.

24. Ou, S. H. 1985. Rice Diseases, 2nd ed. Common. Mycological Institute, Kew, England.

25. Rush, M. C., and Lee, F. N. 1992. Sheath blight. Pages 22-23 in: Compendium of Rice Diseases. R. K. Webster and P. S. Gunnell, eds. American Phytopathological Society Press, St. Paul, MN.

26. Savary, S., Willocquet, L., and Teng, P. S. 1997. Modeling sheath blight epidemics on rice tillers. Agric. Syst. 55:359-384

27. Shahjahan, A. K. M., and. Mew, T. W. 1989 Analysis of rice sheath blight (Rhizoctonia solani) development under tropical condition. Bangladesh J. Plant Pathol. 5:47-52.

28. Van Eeckhout, E., Rush, M. C., and Blackwell, M. 1991. Effects of rate and timing of fungicide applications on incidence and severity of sheath blight and grain yield of rice. Plant Dis. 75:1254-1261.

29. Zhang, W., Webster, E. P., and Leon, C. T. 2005. Response of rice cultivars to V-10029. Weed Technol. 19:307-311. 